\title{
ZMĚNY SPOLEČNÉ OBCHODNÍ POLITIKY PO POSUDKU SOUDNÍHO DVORA EU K DOHODĚ O VOLNÉM OBCHODU EU-SINGAPUR
}

\author{
ONDŘEJ SVOBODA*
}

Abstract: Changes in the Common Commercial Policy after the Court of Justice of the EU's Opinion on the EU-Singapore Free Trade Agreement

The Common commercial policy of the European Union expanded in its scope after the Lisbon Treaty by codification of previous case law of the Court of Justice of the EU (or the European Court of Justice) and an inclusion of foreign direct investment. Still, its boundaries have remained unclear. This state regularly created competences disputes between the European Commission and the Council on which parts of new ambitious free trade agreement negotiated by the Union are of exclusive or shared nature. Finally, in case of the EU-Singapore Free Trade Agreement (EUSFTA), the European Commission decided to request an opinion of the Court on the legal nature of the agreement. Due to its precedential value, the Court's opinion has had significant implications on current and future development of the EU common commercial policy.

Keywords: common commercial policy; European Union; Lisbon Treaty; division of competences; free trade agreement

Klíčová slova: společná obchodní politika; Evropská unie; Lisabonská smlouva; rozdělení pravomocí; dohoda o volném obchodu

DOI: $10.14712 / 23366478.2019 .18$

\section{1. ÚVOD}

Vzhledem k zájmu, který vyvolávají mezinárodní obchodní a investiční dohody sjednávané Evropskou unií, je snad i překvapením, jak malá pozornost byla prozatím věnována posudku Soudního dvora Evropské unie (SDEU) v otázce právní povahy navrhované dohody o volném obchodu mezi EU a Singapurem (EU-Singapore Free Trade Agreement, EUSFTA) a jeho širším dopadům na společnou obchodní politiku EU. ${ }^{1}$ Posudek má přitom výrazný dopad na zapojení členských států EU do schvalova-

* Mgr. Bc. Ondřej Svoboda působí jako interní doktorand na katedře mezinárodního práva Právnické fakulty UK a profesně na oddělení mezinárodního práva Ministerstva průmyslu a obchodu ČR. Text byl zpracován v rámci programu Právnické fakulty Univerzity Karlovy Progres Q04 - Právo v měnícím se světě. Jeho obsah je pouze osobním názorem autora a nevyjadřuje oficiální stanovisko MPO ČR.

1 Výjimku představuje BALAŠ, V. - ŠTURMA, P. Nové mezinárodní dohody na ochranu investic. Praha: Wolters Kluwer, 2018, s. 134. 
cích a ratifikačních procesů všech aktuálně sjednávaných unijních obchodních a investičních dohod. Stejně tak by mohl s ohledem na jeho precedenční charakter do budoucna přesáhnout svým významem obchodní politiku a ovlivnit rozdělení pravomocí v jednotlivých oblastech, které tato dohoda upravuje.

Ř́zení před SDEU bylo vyvrcholením dlouhých sporů mezi Evropskou komisí (dále jen „Komise“) a členskými státy EU ohledně právní povahy dohod o volném obchodu z hlediska rozdělení pravomocí je sjednávat, uzavírat a podepisovat. Je totiž zpravidla nutné, že pokud mezinárodní smlouva spadá do sdílené pravomoci Unie a jejích členských států, jejími stranami byly jak EU, tak členské státy. Tyto spory se projevily především v diskuzích předcházejících dokončení vyjednávání Komplexní hospodářské a obchodní dohody s Kanadou (Comprehensive Economic and Trade Agreement, CETA). Komise musela v tomto př́padě ustoupit tlaku členských států, a přestože CETA považovala za výlučnou v pravomoci EU, byla nakonec schválena Radou jako smíšená. Následující vývoj dal Komisi v určitém smyslu za pravdu, když hrozilo, že se dohodu nepodaří kvůli odporu valonského parlamentu na summitu s Kanadou vůbec podepsat. To se nakonec po dodatečných ústupcích na poslední chvíli podařilo. ${ }^{2}$

Druhou komplexní obchodní dohodou nové generace měla být po CETA právě EUSFTA. Dne 30. ř́ina 2014 proto rozhodlo kolegium komisařů podat žádost o posudek k SDEU týkající se toho, zda tato dohoda spadá do výlučné pravomoci Unie, či nikoliv. O důležitosti sporu svědčí také fakt, že s výjimkou Chorvatska a Malty, které se do řízení nezapojily, se před SDEU všechny členské státy EU vyjádřily ve prospěch smíšené povahy dohody. Ta byla nakonec ze strany SDEU potvrzena, ačkoli v úzkém pojetí.

Autor v tomto př́spěvku po části věnující se právnímu zakotvení společné obchodní politiky EU stručně představí hlavní sporné právní otázky v daném př́ípadě i jeho samotný průběh a výsledek. Cílem není vyčerpávající analýza posudku, ale zaměření se na nejdůležitější závěry, které budou relevantní pro další směřování společné obchodní politiky EU. Na jejich základě bude také posouzen nový př́stup, který EU přijala k uzavírání obchodních a investičních dohod, včetně možných pozitivních a negativních důsledků, které přináší. Samotné závěry SDEU přitom nemohou být překvapivé. SDEU v posudku 2/15 navazuje na předchozí judikaturu, ve které hranice společné obchodní politiky, a tedy i výlučné pravomoci Unie, rozšiřuje.

\section{NEJASNÉ HRANICE SPOLEČNÉ OBCHODNÍ POLITIKY V LISABONSKÉ SMLOUVĚ}

Společná obchodní politika EU je upravena v čl. 206 a 207 Smlouvy o fungování EU (SFEU) a její výlučná povaha je pak stanovena v čl. 3 Smlouvy o Evropské unii (SEU). Na první pohled je při srovnání s před lisabonskou úpravou v čl. 113 Smlou-

2 Blíže viz LAIRD, I. - PETILLION, F. Comprehensive Economic and Trade Agreement, ISDS and the Belgian Veto: A Warning of Failure for Future Trade Agreements with the EU? Global Trade and Customs Journal, 2017, Vol. 12, č. 4, s. 167-174; SVOBODA, O. Uzavření Komplexní hospodářské a obchodní dohody EU-Kanada (CETA) a výzvy efektivnímu vedení společné obchodní politiky. Současná Evropa, 2017, vol. 22, č. 2, s. 78-88. 
vy o Evropských společenstvích evidentní, že její pojetí bylo Lisabonskou smlouvou dále rozšiřreno a prohloubeno, přičemž došlo ke konsolidaci dřívějších rozhodnutí Evropského soudního dvora (ESD), resp. jeho nástupce SDEU, který „nikdy neváhal potvrdit výlučnou povahu pravomocí Společenství k obchodní politice". 3 Toho v minulosti Komise opakovaně využila pro posílení své role a zvýšení vlivu v politikách, u kterých si Unie nárokuje pravomoc rozporovanou členskými státy. ${ }^{4}$

Společná obchodní politika tak v polisabonském období mj. obsahuje služby, ${ }^{5}$ práva k duševnímu vlastnictví a př́mé zahraniční investice, které se jako nové oblasti ve výlučné pravomoci Unie staly ohniskem nových kompetenčních sporů. Je ale také důležité mít na paměti, že tento výčet má pouze demonstrativní povahu. ${ }^{6}$ Ve skutečnosti je společná obchodní politika širší a otevřená dalšímu rozšíření o oblasti související se zahraničním obchodem. ${ }^{7}$ Ke zpřesnění jejího nového rámce přispěl SDEU ve dvou nedávných soudních sporech, které ř́zení $2 / 15$ předcházely. ${ }^{8}$

Předmětem rozsudku ve věci C-414/11 byla žádost o rozhodnutí o předběžné otázce týkající se výkladu Dohody TRIPS položené řeckým soudem. SDEU mj. uvedl, že došlo $\mathrm{k}$ „výraznému vývoji primárního práva“ a významným změnám mezi předchozí a současnou úpravou v primárním právu. ${ }^{9}$ Podle SDEU Dohoda TRIPS navíc vykazuje zvláštní spojitost s mezinárodním obchodem, nebot' je „,nedílnou součástí systému WTO a představuje jednu z hlavních mnohostranných dohod, na nichž je tento systém založen “. ${ }^{10}$ Vzhledem k tomu, že pravidla obsažená v Dohodě TRIPS směřují k liberalizaci mezinárodního obchodu, spadají podle SDEU do sféry společné obchodní politiky. ${ }^{11}$

Podobně v rozsudku ve věci C-137/12 se SDEU přiklonil k extenzivnímu výkladu společné obchodní politiky, tentokrát v oblasti služeb. Konkrétně Soud zkoumal, zda rozhodnutí Rady o podpisu Evropské úmluvy o právní ochraně služeb s podmíněným

3 EECKHOUT, P. EU External Relations Law. 2. vyd. Oxford: Oxford University Press, 2011, s. 18. Pro stručný přehled historického vývoje judikatury viz např. DE WAELE, H. Legal Dynamics of EU External Relations: Dissecting a Layered Global Player. Berlin: Springer, 2017, s. 83 a násl.; ROSSI, L. S. Does the Lisbon Treaty Provide a Clearer Separation of Competences between EU and Member States? In: BIONDI, A. - EECKHOUT, P. - RIPLEY, S. (eds.). EU Law after Lisbon. Oxford: Oxford University Publishing, 2012, s. 89-90; nebo LECYZKIEWCZ, D. Common Commercial Policy: The Expanding Competence of the European Union in the Area of International Trade. German Law Journal, 2005, vol. 6, č. 11 , s. $1673-1685$.

4 BASEDOW, J. R. The EU in the Global Investment Regime: The Commission Entrepreneurship, Incremental Institutional Change and Business Lethargy. London, Abingdon, New York: Routledge, 2018, s. 22.

5 S výjimkou dopravních služeb, které podle čl. 207 odst. 5 zůstávají ve sdílené pravomoci. V prípadě, že nicméně obsah konkrétní dohody odráží v této oblasti existující internal acquis, jedná o výlučnou pravomoc podle čl. 3 odst. 2 SFEU.

6 SVOBODA, P. Právo vnějších vztahů. 1. vyd. Praha: C. H. Beck, 2010, s. 127.

7 KADDOUS, C. The Transformation of the EU Common Commercial Policy. In: EECKHOUT, P. - LOPEZ-ESCUDERO, M. (eds.). The European Union's External Action in Times of Crisis. Oxford: Hart Publishing, 2016, s. 434.

8 C-414/11, Daiichi Sankyo Co. Ltd a Sanofi-Aventis Deutschland GmbH proti DEMO Anonymos Viomichaniki kai Emporiki Etairia Farmakon, ECLI:EU:C:2013:520 (dále jen „C-414/11“); C-137/12, Evropská komise proti Radě Evropské unie, ECLI:EU:C:2013:441 (dále jen „C-137/12“).

9 C-414/11, bod 48.

10 Tamtéž, bod 53 .

11 Bliže viz např. VAN DAMME, I. Case C-414/11 Daiichi: The Impact of the Lisbon Treaty on the Competence of the European Union over the TRIPS Agreement. Cambridge International Law Journal, 2015, vol. 4 , č. 1, s. 73-87. 
přistupem a služeb tvořených podmíněným přístupem (dále jen „Úmluva“) je založeno na správných právních základech s ohledem na fakt, že upravuje mj. sankční opatření mající trestněprávní povahu. SDEU ve svém rozhodnutí uplatnil při zhodnocení výběru právního základu unijního rozhodnutí test centra gravitace (,centre of gravity test“), tj. přezkum opatření, zda sleduje dvojí účel, nebo má dvě složky. V souvislosti se společnou obchodní politikou SDEU ustáleně judikuje, že unijní akt spadá do společné obchodní politiky, pokud se „týká zvláště mezinárodního obchodu, poněvadž je jeho účelem především podpora, usnadnění nebo úprava tohoto obchodu a má na něj přímé a bezprostřední účinky“. ${ }^{12}$ Rozhodnutí Rady tak podle názoru SDEU spadá do společné obchodní politiky, kdy jeho hlavním účelem je rozšířit ochranu dotčených služeb mimo státy EU a vykazuje tak zvláštní spojitost s mezinárodním obchodem s uvedenými službami. ${ }^{13} \mathrm{~V}$ rozsudku C-137/12 tedy SDEU stanovil, že při posouzení, zda unijní akt spadá pod společnou obchodní politiku ${ }^{14}$ podle čl. 207 SFEU, je nutné se zabývat dvěma otázkami. Zaprvé, jestli se akt zvláště týká mezinárodního obchodu, a zadruhé, jestli má na mezinárodní obchod př́mé a bezprostřední účinky. Pokud je odpověd' kladná, pohybujeme se v oblasti unijní výlučné pravomoci.

Obě rozhodnutí SDEU představovaly významný posun v oblasti služeb a práv duševního vlastnictví, a podle některých komentátorů dokonce „renesanci společné obchodní politiky““. ${ }^{15}$ Současně potvrdily, že ani po přijetí Lisabonské smlouvy není debata o jejím rozsahu a povaze uzavřena stejně jako trend extenzivního výkladu ze strany SDEU. Tyto závěry hrály nepochybně roli v úvahách Komise posunout hranice výlučné kompetence ještě dále prostřednictvím posouzení právní povahy EUSFTA.

\section{DOHODA O VOLNÉM OBCHODU EU-SINGAPUR}

Evropská unie príijala strategii sjednávání bilaterálních, popř. regionálních dohod o volném obchodu (free trade agreements, FTAs) po dlouhotrvající patové situaci ve WTO v r. 2006. ${ }^{16}$ Nové FTAs měly mít „komplexní a ambiciózní pokrytí a usilovat o co nejvyšší míru liberalizace obchodu“ ${ }^{17}$ Mezi prioritní země byly při přihlédnutí k různým kritériím, jako např. tržní potenciál, zařazeny také státy Sdružení zemí jihovýchodní Asie (ASEAN). ${ }^{18}$ Bylo pak už jen logickým krokem, když se v březnu 2010 zahájila obchodní vyjednávání se Singapurem a dodatečně byl v červenci 2011 Radou EU schválen mandát i $\mathrm{k}$ jednání o kapitole o ochraně investic. ${ }^{19}$ Jednání s výjimkou

12 C-137/12, bod 57 .

13 Tamtéž, bod 65.

14 Resp. má „Zvláštní spojitost se společnou obchodní politikou“.

15 DE LA TORRE, F. C. The Court of Justice and External Competences After Lisbon: Some Reflections on the Latest Case Law. In: EECKHOUT, P. - LOPEZ-ESCUDERO, M. (eds.). The European Union's External Action in Times of Crisis. Oxford: Hart Publishing, 2016, s. 131.

16 Evropská komise. Sdělení Komise Globální Evropa: konkurenceschopnost ve světě. $\mathrm{KOM(2006)} \mathrm{567,}$ 4. 10. 2006.

17 Tamtéž, s. 9.

18 Tamtéž, s. 8.

19 Council of the European Union. Council extends mandate for free trade talks with ASEAN. 15000/13 PRESSE 424, 18. 10. 2013. 
investiční kapitoly byla ukončena v prosinci 2012 (text byl parafován v záŕí 2013). ${ }^{20}$ V polovině ř́ijna 2014 byla dokončena i jednání o investiční kapitole (s parafováním v květnu 2015).

Co se týče samotného obsahu, dohoda se celkem skládala ze 17 kapitol. Její pokrytí odpovídalo ambiciózním představám vyjednavačů a jednalo se o komplexní moderní obchodní dohodu s širokým záběrem.

Kapitoly 2 až 7 se věnovaly obchodu zbožím a upravovaly vstup na trh se zbožím, ochranná opatření, technické překážky obchodu, sanitární a fytosanitární opatření, usnadňování celních procedur a odstranění netarifních překážek v zařízeních pro obnovitelnou energii a dalších konkrétních sektorech, jako automobily, elektronika či farmaceutika. V praktické rovině se smluvní strany zavázaly k odstranění všech cel během pěti let od vstupu dohody v platnost.

Kapitoly 8 a 9 upravovaly služby, usazení, elektronický obchod a ochranu investic, včetně mechanismu řešení sporů investor-stát (ISDS). V oblasti obchodu službami se očekával největší přínos dohody, protože komplexní liberalizace mnoha sektorů služeb se měla stát jejím klíčovým atributem. Bylo dosaženo ambiciózních závazků v př́ípadě telekomunikačních, environmentálních, finančních, inženýrských, architektonických, poštovních, námořních a IT služeb. V oblasti ochrany investic dohoda zajišt'ovala stabilní a spravedlivé prostředí pro přímé i nepřimé investice při zachování práva smluvních stran regulovat právní prostředí ve veřejném zájmu. Tato kapitola se stala pravděpodobně nejkontroverznější částí dohody, protože v souvislosti s paralelně probíhajícími unijními vyjednáváními se Spojenými státy o Transatlantickém obchodním a investičním partnerstvím (TTIP) se podle komisařky pro obchod Cecilie Malmström ISDS stalo „nejtoxičtější zkratkou v Evropě“. 21

V kapitolách 10 až 14 byla upravena pravidla související s obchodem. Především se jednalo o veřejné zakázky, ochranu práv $\mathrm{k}$ duševnímu vlastnictví, hospodářskou soutěž, vztah obchodu a udržitelného rozvoje a transparentnost. V oblasti veřejných zakázek se smluvní strany shodly na rozšíření svých závazků nad Dohody WTO o vládních zakázkách, ke které už dříve přistoupily. V oblasti ochrany práv k duševnímu vlastnictví dohoda stanovila základní pravidla jejich vymáhání mj. i na hranicích, ale neobsahovala trestní vymáhání. Pokud jde o zeměpisná označení (GIs), smluvní strany se dohodly na vytvoření registru zajišstujícího ochranu GIs a poskytujícího tak větší transparentnost a jistotu. V kapitole týkající se obchodu a udržitelného rozvoje se zakotvilo dodržování mezinárodních standardů v oblasti pracovních podmínek a ochrany životního prostředí. Obsahovala také otázky odpovědného chování firem, udržitelného spravování př́rodních zdrojů a způsob zapojení občanské společnosti.

Závěrečné kapitoly 15 až17 obsahovaly postup pro řešení sporů, institucionální, obecná a závěrečná ustanovení. Mechanismus pro řešení sporů vycházel ze vzoru procesu ve WTO, ale právě na základě zkušeností získaných z WTO byl formulován ještě

20 European Commission. EU and Singapore present text of comprehensive free trade agreement. 20. zárí 2013.

21 PALMER, D. Malmström to unveil investment dispute plan for TTIP. In: POLITICO [online]. 5. 5. 2015 [cit. 4. 1. 2019]. Dostupné na: http://www.politico.eu/article/eu-malmstrom-unveils-ttip-investment -dispute-settlement-plan/. Blíže viz např. SVOBODA, O. TTIP and ISDS: not irreconcilable acronyms. Czech Yearbook of Public \& Private International Law, 2015, vol. 6, s. 345-354. 
detailněji. Navíc byla zahrnuta také možnost mediace. Důležitým prvkem bylo také založení společného výboru, který měl zastřešovat specializované podvýbory a sloužit $\mathrm{k}$ diskuzi smluvních stran o implementaci dohody.

Svým obsahem tak EUSFTA odrážela ambici komplexní FTA upravující vzájemné obchodní vztahy mezi EU a Singapurem v celé jejich šíri. EU dohodu také plánovala využít jako „základní kámen“ pro budování obchodních vztahů s dalšími zeměmi ASEAN s perspektivou pozdější megaregionální dohody EU-ASEAN. ${ }^{22}$

\section{4. ̌ÍZENÍ K ŽÁDOSTI O POSUDEK 2/15}

Široký rozsah nové generace FTAs jako CETA a EUSFTA vyvolaly nejistotu ohledně pravomocí nad některými zahrnutými oblastmi. ${ }^{23}$ Související kompetenční spory vedly Komisi již v r. 2014 k př́pravě podání žádosti o posudek. Tehdejší komisař pro obchod Karel De Gucht tento krok odůvodnil potřebou vyjasnit pokračující rozdílné pohledy Komise a Rady ohledně výkladu Lisabonské smlouvy pro zlepšení předvídatelnosti EU vůči jejím partnerům. ${ }^{24}$ Situace, která předcházela podpisu CETA, jen utvrdila Komisi v její snaze o potvrzení výlučné unijní pravomoci nad všemi oblastmi upravenými v těchto dohodách a ve své žádosti z 10. července 2015 adresované SDEU předložila k posouzení následující otázky:

„Má Unie samotná potřebnou pravomoc k podpisu a uzavření dohody o volném obchodu se Singapurem? Konkrétně:

- Která ustanovení dohody spadají do výlučné pravomoci Unie?

- Která ustanovení dohody spadají do sdílené pravomoci Unie?

- Spadá některé ustanovení dohody do výlučné pravomoci členských států?“25

Komise tedy požádala SDEU o názor, zda má Unie samotná potřebnou pravomoc k podpisu EUSFTA, což v praktické rovině znamenalo zodpovědět, která ustanovení spadají do výlučné pravomoci Unie, která do sdílené a zda některá ustanovení spadají do výlučné pravomoci členských států.

Pro Komisi byla celá dohoda ve výlučné pravomoci Unie. ${ }^{26}$ Podle názoru Rady a členských státi však byla dohoda smíšená a pro potřebu účasti členských států na dohodě nejsilněji hovořila kapitola 8 (Služby, usazování a e-commerce), kapitola 9 (Investice) ${ }^{27}$ a kapitola 13 (Obchod a udržitelný rozvoj), dále rovněž kapitola 7 (Netarifní

22 SERRANO, A. S. From External Policy to Free Trade: The EU-Singapore Free Trade Agreement. In: EECKHOUT, P. - LOPEZ-ESCUDERO, M. (eds.). The European Union's External Action in Times of Crisis. Oxford: Hart Publishing, 2016, s. 507.

23 ARAUJO, B. A. M. The EU Deep Trade Agenda. Oxford: Oxford University Press, 2016, s. 73.

24 European Commission. Singapore: The Commission to Request a Court of Justice Opinion on the Trade Deal. 30. 10. 2014.

25 Posudek A-2/15 ze 16. května 2017, ECLI:EU:C:2017:376, bod 1.

26 Pro dlouhodobě zastávané argumenty Komise viz HOFFMEISTER, F. Of Transferred Competence, Institutional Balance and Judicial Autonomy - Constitutional Developments in EU Trade Policy Seven Years after Lisbon. In: CZUCZAI, J. - NAERT, F. (eds.). The EU as a Global Actor - Bridging Legal Theory and Practice: Liber Amicorum in honour of Ricardo Gosalbo Bono. Leiden: Brill/Nijhoff, 2017, s. 310-317.

27 Pozice Rady k investicím je dobře zdokumentována, např. v mandátu pro vyjednávání o TTIP: „The aim of negotiations on investment will be to negotiate investment liberalisation and protection provisions in- 
překážky obchodu a investice do obnovitelných zdrojů energie), kapitola 11 (Duševní vlastnictví) a kapitola 14 (Transparentnost).

V rámci soudního řízení proběhlo v Lucemburku ve dnech 13. a 14. záŕí 2016 slyšení, přičemž soudci SDEU zasedali v plénu, což jen potvrdilo důležitost celého př́ípadu. Ve svém úvodním vystoupení Komise připomněla současný rozsah společné obchodní politiky v čl. 207 SFEU. Ukázala také na př́íkladu FTA s Jižní Koreou, která vstoupila v platnost až pět let od podpisu, že smíšenost s sebou nese praktické negativní důsledky a ani prozatímní provádění není schopno platnost dohody plně nahradit, když se prozatímně provádějí jen záležitosti v unijní výlučné pravomoci. Za pozornost také stojí pozice Komise k čl. 9.10 EUSFTA, na základě kterého mají být dvoustranné dohody o podpoře a ochraně investic (bilateral investment treaties, BITs) členských států EU nahrazeny EUSFTA. Podle Komise v tomto př́ípadě Unie jedná jako sukcesor členských států podle mezinárodního práva. To má potvrzovat i předchozí praxe s odkazem na historický př́klad nástupnictví v kontextu GATT. ${ }^{28}$ Ke kapitole o udržitelném rozvoji Komise zdůraznila, že EU musí vést obchodní politiku v souladu s horizontálními požadavky Smluv a obecnými principy unijního práva a některá ustanovení jsou pouze deklaratorní povahy. Je zde navíc již praxe, kdy je udržitelný rozvoj zařazen pod společnou obchodní politiku v rámci systému všeobecných celních preferencí (GSP). Na podporu Komise vystoupil následně Evropský parlament, podle kterého EUSFTA spadá převážně pod společnou obchodní politiku a právní základ by měl mít jen čl. 207 SFEU, protože ostatní části jsou jen doplňkové.

Rada na úvod zdůraznila význam posudku a jeho precedenční dopady na sjednávání dalších dohod a ohradila se vưči extenzivnímu př́stupu Komise, který nemá oporu ani v judikatuře, ani ve Smlouvách. Ve vztahu k investiční kapitole zdůraznila, že obsahuje velmi širokou definici investic, která bezesporu zahrnuje i portfoliové investice, které nejsou čl. 207 SFEU upraveny. Argumentovala také kapitolou o udržitelném rozvoji, která obsahuje substantivní ustanovení v neobchodních věcech (vč. pracovně-právních podmínek, které jsou zcela mimo dosah společné obchodní politiky) a je zcela samostatná, což dokládá i vlastní systém řešení sporů. Na podporu Rady následně vystoupilo 16 členských států (včetně ČR), které měly řadu shodných argumentů, at' v otázkách portfoliových investic, vyvlastnění, dopravních služeb nebo udržitelného rozvoje. Řada z nich také upozornila, že podle mezinárodního práva nemůže být platnost stávajících BITs, které mají členské státy uzavřeny se Singapurem, dotčena evropským právem. Nelze je tedy změnit bez souhlasu těchto států, a proto k nim ani EU nemůže mít výlučnou pravomoc. ${ }^{29}$

cluding areas of mixed competence, such as portfolio investment, property and expropriation aspects, on the basis of the highest levels of liberalisation and highest standards of protection that both Parties have negotiated to date." Council of the European Union. Directives for the negotiation on the Transatlantic Trade and Investment Partnership between the European Union and the United States of America. ST 11103/13 DCL 1, 9. 10. 2014, odst. 22.

28 C-21/72, International Fruit Company NV and Others v Produktschap voor Groenten en Fruit, ECLI:EU:C:1972:115.

29 Autor se slyšení osobně účastnil a popis v této kapitole vychází z jeho osobních poznámek. 


\section{POSUDEK SDEU}

Dlouho očekávané rozhodnutí SDEU bylo zveřejněno dne 16 . května 2017. Ve svém posudku SDEU konstatoval, že EUSFTA obsahuje jak části, které spadají do výlučné pravomoci, tak rovněž části, jež spadají do sdílené pravomoci EU a jejích členských států, kde je také v rámci národních ratifikačních procesů nezbytné zapojení jejich národních parlamentů. $Z$ tohoto důvodu není možné uzavřít EUSFTA jako výlučnou a musí být uzavřena jako smíšená dohoda jednak jménem EU, tak i jejích členských států. Při podrobnějším pohledu SDEU označil jako výlučné krom jiného následující části dohody:

- kapitolu týkající se přístupu na trh, včetně opatření na ochranu obchodu, technických překážek obchodu nebo celních předpisů;

- závazky týkající se obchodních aspektů ochrany duševního vlastnictví, hospodářské soutěže a udržitelného rozvoje v oblasti hospodářství, sociálních věcí a životního prostředí;

- oblast služeb, usazení a dočasné př́tomnosti fyzických osob a také úprava zadávání veřejných zakázek s výjimkou vybraných služeb v oblasti dopravy;

- ustanovení ohledně př́mých zahraničních investic.

SDEU zařadil tyto oblasti do výlučné pravomoci, protože to jednak prŕmo stanovuje primární právo EU (článek 3 odst. 1 SFEU), nebo tyto části spadají do výlučné pravomoci EU, jelikož je to nutné k tomu, aby EU mohla vykonávat svou vnitřní pravomoc, nebo jejich zařazení do EUSFTA může ovlivnit nebo změnit společná pravidla pro danou oblast (článek 3 odst. 2 SFEU).

Za části, které spadají do smíšené pravomoci EU a jejích členských států, SDEU označil:

- oblast portfoliových investic (tzn. nepř́mých, uskutečňovaných bez úmyslu ovlivňovat řízení podniků);

- řešení sporů mezi investory a státem;

- ustanovení pomocná k těmto částem EUSFTA (např. institucionální). ${ }^{30}$

Tento závěr nebyl př́liš překvapivý, protože převážná část expertů zastávala podobný názor. ${ }^{31}$ Nalezená smíšenost dohody je také v souladu se stanoviskem generálního advokáta zveřejněném v prosinci 2016, ačkoliv ve významně užším rozsahu. ${ }^{32}$ Argumentace SDEU je ve srovnání se stanoviskem generálního advokáta mnohem obecnější.

$\mathrm{V}$ př́ípadě nejrozporovanějších oblastí SDEU vycházel ze zavedeného konceptu ,zvláštní spojitosti s mezinárodním obchodem s př́mými a bezprostředními účinky na tento obchod“, v daném př́padě obchod mezi Unií a Singapurem. Tu nalezl

30 Posudek A-2/15, bod 309.

31 Např. BISCHOFF, J. A. Just a little bit of "mixity"? The EU's role in the field of international investment protection law. Common Market Law Review, 2011, vol. 48, č. 5, s. 1527-1569; FECÁK, T. Mezinárodní dohody o ochrané investic a právo Evropské unie. Praha: Wolters Kluwer, 2015, s. 221.

32 Podle generálního advokáta zůstaly taky dopravní služby ve sdílené pravomoci (společně s úpravou veřejných zakázek, které se $\mathrm{k}$ nim vztahují), neobchodní aspekty práv $\mathrm{k}$ duševnímu vlastnictví a části kapitoly $\mathrm{k}$ udržitelnému rozvoji. Ve výlučné pravomoci členských států pak zcela zůstala problematika ukončení BITs členských států. Stanovisko generálního advokáta E. Sharpston ve věci posudku A-2/15, Dohoda o volném obchodu se Singapurem, EU:C:2016:992. 
mj. u úpravy vyvlastnění a všech standardů zacházení v investiční ochraně (národní zacházení, doložka nejvyšších výhod, standard spravedlivého a rovného zacházení), pokud se vztahuje k př́mým zahraničním investicím..$^{33}$

Také politiky udržitelného rozvoje, ochrany životního prostředí nebo ochrany pracovních standardů jsou podle SDEU přímo spojeny s mezinárodním obchodem, a tak jsou ,integrální součástí výlučné obchodní pravomoci EU““. ${ }^{34}$ SDEU sice připustil, že je pravda, že výlučná pravomoc Unie nemůže být uplatňována k úpravě úrovní sociální ochrany a ochrany životního prostředí. Zároveň ale vzápětí dodal, že Smluvní strany v dané kapitole deklarují, že „,nemají v úmyslu harmonizovat své pracovní či environmentální normy“. I proto uvedená kapitola spadá do výlučné pravomoci Unie. ${ }^{35}$ Zůstává nicméně sporné, nakolik podrobná úprava udržitelného rozvoje může být ve výlučné pravomoci Unie, zvláště pokud bude mít normativní charakter.

Oblast portfoliových investic zařadil SDEU do smíšené pravomoci z toho důvodu, protože vzhledem $\mathrm{k}$ neexistenci společných pravidel pro tuto oblast, vytvořených sekundární legislativou EU, není možné, aby uzavření EUSFTA mohlo ovlivnit společná pravidla EU ve smyslu čl. 3 odst. 2 SFEU. ${ }^{36}$ Nezodpovězenou otázkou však zůstává, kde leží přesné hranice mezi př́mými a portfoliovými investicemi, což se může stát v budoucnu předmětem dalších soudních sporů. ${ }^{37}$

Režim řešení sporů mezi investory a státy je druhým významným prvkem spadajícím do oblasti sdílené pravomoci. Důvodem je to, že členské státy musí souhlasit s vynětím těchto sporů z jejich soudní jurisdikce. Proto je také nezbytný souhlas členských států $\mathrm{s}$ jeho vytvořením. ${ }^{38}$ Tento závěr logicky ústí $\mathrm{v}$ účast členských států jako smluvních stran a smíšenost dohody. Tato logika se přitom nevztahuje pouze na posuzované ISDS, ale i další obdobné mechanismy, např. systém investičního soudu (ICS) ${ }^{39}$ který ISDS v unijních dohodách nahrazuje jako legitimnější mechanismus řešení těchto sporů. 40

Doktrína implicitních pravomocí ${ }^{41}$ (známá také na základě historického rozsudku jako doktrína AETR $)^{42}$ byla potvrzena u dopravních služeb. SDEU ovšem uplatnil mnohem nižší standard pro její aplikaci. Podle SDEU jsou dopravní služby, at' se jedná o železniční, silniční nebo námořní dopravu, zahrnuté v EUSFTA již převážně upraveny unijním právem, a proto spadají do výlučné unijní pravomoci. ${ }^{43}$

\footnotetext{
3 Posudek A-2/15, body 96, 109.

4 Tamtéž, bod 147.

5 Tamtéž, body 164-167.

6 Tamtéž, bod 230 .

37 LAVRANOS, N. Mixed Exclusivity: The CJEU's Opinion on the EU-Singapore FTA. Investment Law and Arbitration Review, 2017, vol. 2, s. 14.

38 Posudek A-2/15, bod 292.

39 LAVRANOS, c. d., s. 19.

40 Pro kritickou analýzu viz BALAŠ, V. - ŠTURMA, P. Nové mezinárodní dohody na ochranu investic. Praha: Wolters Kluwer, 2018, s. 89 a násl.; SVOBODA, O. Systém investičního soudu: Překotný rozchod Evropské unie s investiční arbitráží. Právník, 2019, vol. 158, č. 4, s. 390-406.

41 Tato pravomoc se navíc považuje za výlučnou při sjednávání mezinárodních smluv. Lisabonská smlouva také v tomto směru kodifikovala existující judikaturu v čl. 3 odst. 2 SFEU.

42 C-22/70, Commission of the European Communities $v$ Council of the European Communities, EU:C:1971:32, body 17 a násl.

43 Posudek A-2/15, body 168-218.
} 
Za pozornost také stojí osud bilaterálních investičních dohod členských států EU, které mají uzavřené se Singapurem. EUSFTA tuto otázku upravovala zvláštním ustanovením (čl. 9.10), které stanovovalo, že tyto dohody přestanou po vstupu EUSFTA v platnost platit a budou nahrazeny EUSFTA. SDEU v tomto bodě přistoupil na argument Komise, že po přesunu pravomocí může být takové ustanovení ukončující platnost mezinárodních smluv členských států zahrnuto ve výlučné dohodě. ${ }^{44}$ Tento závěr je nicméně velice problematický z pohledu mezinárodního práva.

Pro další vývoj je ale snad nejdůležitější závěr, že SDEU považuje unijní FTAs v aktuálně navrhovaném rozsahu $\mathrm{v}$ jejich obchodní části za mezinárodní dohody spadající do výlučné pravomoci EU, u nichž není potřeba s jejich uzavřením souhlas národních parlamentů členských států EU. Se zahrnutím investiční kapitoly obsahující úpravu portfoliových investic a systém řešení sporů mezi investorem a státem se z FTAs stávají smíšené dohody, kdy je zapojení parlamentů členských států do schvalovacího procesu nezbytné. Toto zjištění následně významně ovlivnilo další směřování unijní společné obchodní politiky.

\section{NOVÁ ARCHITEKTURA DOHOD O VOLNÉM OBCHODU EU}

Co se týče dalších kroků, posudek 2/15 nestanovil, jak postupovat u budoucích FTAs, ani nenabídl žádná doporučení. Posudek však má významnou precedenční váhu a měl zásadní vliv na další diskuze mezi unijními institucemi o tom, jak usnadnit a urychlit schvalování dalších unijních obchodních dohod.

Podle očekávání ${ }^{45}$ Komise zvolila nejsnadnější cestu, a to změnou rozsahu a architektury unijních FTAs. V rámci diskuze s Radou navrhla nový př́stup pro vyjednávání a uzavírání obchodních dohod, který spočíval v oddělení části ochrany investic, tedy oblasti sdílené pravomoci, a paralelní vyjednávání čistě obchodních dohod a dohod o ochraně investic (investment protection agreement, IPA). ${ }^{46}$ Protože obchodní část je zcela ve výlučné pravomoci Unie, bude stačit schválení samostatných obchodních dohod pouze ze strany Rady a Evropského parlamentu, což by mělo usnadnit a urychlit jejich schvalování.

Rada navrhovaný př́stup, pravděpodobně také $\mathrm{v}$ zájmu zefektivnění společné obchodní politiky, přijala oficiálně v květnu $2018 .{ }^{47}$ Rozhodnutí Rady již předcházelo rozdělení EUSFTA v uvažovaných parametrech. V dubnu 2018 bylo oznámeno její rozdělení do dvou samostatných dohod, obchodní a investiční. ${ }^{48}$ Obě dohody jsou již nyní

44 Tamtéž, body 248-249.

45 European Parliament. Free Trade Agreement between the EU and the Republic of Singapore - Analysis. Brusel, 2018, s. 75; LAVRANOS, c. d., s. 26.

46 Další z možných variant mohlo být také zúžení samotného rozsahu investiční ochrany o portfoliové investice a vyjmutí řešení sporů. Takový př́stup by nicméně významným způsobem omezil rozsah poskytované ochrany evropským investorům.

47 Council of the European Union. Outcome of the Council Meeting, 3618th Council Meeting. 9102/18, 22. 5. 2018 .

48 Evropská komise. Obchod: Evropská komise navrhuje podpis a uzavřeni dohod s Japonskem a Singapurem. 18. 4. 2018. 
schváleny Radou ${ }^{49}$ a dne 18 . ŕíjna 2018 byly podepsány na summitu ASEM. ${ }^{50}$ Zatímco $^{2}$ dohoda o ochraně investic bude předložena parlamentům všech členských států EU a čeká ji nejistá cesta postupné ratifikace, obchodní dohoda bude již vyžadovat pouze souhlas Evropského parlamentu. Podobný scénář je očekáván u dohody o volném obchodu s Vietnamem, která byla také původně sjednána jako komplexní. Nicméně po posudku SDEU z ní bude oddělena investiční část, ze které se stane samostatná dohoda. V tomto výčtu pak nesmí chybět ani dohoda mezi EU a Japonskem. I ta měla podle původních ambicí vyjednavačů na obou stranách zahrnovat obchodní i investiční části. Nicméně pro neschopnost nalézt shodu nad mechanismem řešení investičních sporů, byly investice vyjmuty, aby celou dohodu „nezdržovaly“. Čistě obchodní dohoda byla podepsána v červenci 2018 , zatímco investiční vyjednávání stále pokračují. ${ }^{51}$

Tento nový př́stup ve sjednávání obchodních a investičních dohod má tedy za první rok svého uplatňování počáteční úspěchy. $V$ dlouhodobém horizontu však může mít i své stinné stránky.

V procesu schvalování obchodních dohod odpadá povinnost jejich ratifikace národními parlamenty, které věnují obchodním otázkám čím dál větší pozornost. ${ }^{52} \mathrm{Na}$ jednu stranu se tak předejde komplikacím, které provázely např. schvalování dohody CETA, na druhou stranu je zde otázka transparentnosti a legitimity obchodní politiky. Sjednávání výlučných dohod, $v$ jehož procesu nehrají národní parlamenty žádnou roli, může mít negativní dopad na postoj občanské společnosti, která tyto dohody pozorně sleduje a je k nim převážně kritická.

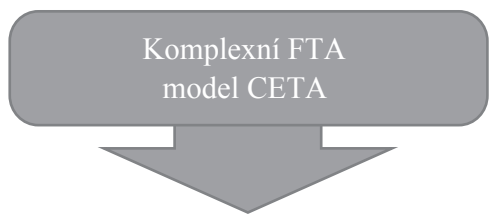

obchodní a investiční části

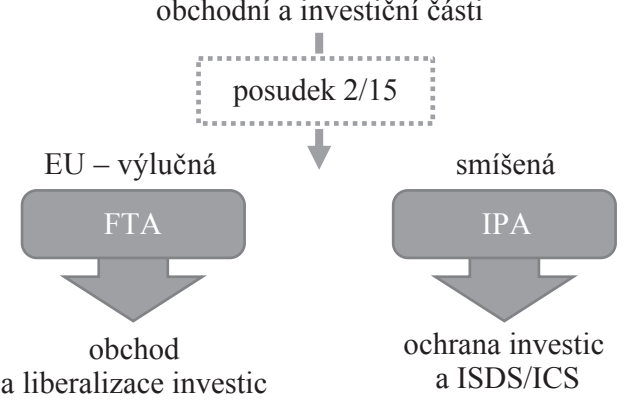

Schéma nové architektury obchodnich a investičních dohod EU

49 Rada Evropské unie. EU-Singapur: Rada přijala rozhodnutí o podpisu obchodní a investiční dohody. 15. 10. 2018.

50 Evropská komise. EU a Singapur prohlubuji hospodářské a politické vztahy. 19. 10. 2018.

51 Evropská komise. Summit EU-Japonsko: přelomový okamžik pro obchod a spolupráci. 17. 7. 2018.

52 ROEDERER-RYNNING, C. - KALLETRUP, M. National parliaments and the new contentiousness of trade. Journal of European Integration, 2017, vol. 39, č. 7, s. 811-825. 
Nadále také platí, že může být obtížné udělat přesnou dělicí čáru mezi pravomocemi výlučnými a sdílenými. Jakékoli snahy Komise rozšířit rozsah FTAs o další oblasti, např. protikorupční ustanovení, nebo ustanovení zaměřená na ochranu spotřebitele, ${ }^{53}$ s sebou mohou nést riziko zavedení prvku smíšenosti. Pro snazší schvalovací proces tak může Komise rezignovat na ambiciózní obchodní politiku a do budoucna se omezovat na oblasti výlučné unijní pravomoci.

\title{
7. ZÁVĚR
}

V oblasti společné politiky lze dlouhodobě v judikatuře SDEU pozorovat tendenci extenzivního výkladu výlučných unijních pravomocí na základě zásady dynamismu vycházející z teze, že společná obchodní politika je především výsledkem progresivního vývoje a nevztahuje se na pouhou liberalizaci obchodu. ${ }^{54}$ Tento př́stup SDEU uplatňuje i v polisabonském období a posudek $2 / 15$ je zatím posledním rozhodnutím $\mathrm{v}$ této bohaté judikatuře SDEU.

Význam posudku musí být v první řadě chápán v kontextu obchodní strategie Unie, která na začátku tisíciletí zahájila sérii bilaterálních vyjednávání o komplexních FTAs. Ty se staly hlavním nástrojem obchodní spolupráce, kdy otvírají nejen trhy, ale poskytují i rámec pro lepší nastavení regulace řady oblastí souvisejících s obchodem. ${ }^{55}$ Tímto jdou svým obsahem nad obvyklý obchodní rámec, kdy se nově snaží regulovat otázky udržitelného rozvoje nebo obsahují mechanismus řešení investičních sporů. Těmto vysokým ambicím také odpovídal výsledný text EUSFTA. Jelikož však tyto oblasti nejsou explicitně uvedeny v Lisabonské smlouvě jako součást společné obchodní politiky, bylo pouze otázkou času, kdy rozdílné nazírání Rady a Komise a kompetenční spory mezi těmito institucemi skončí před SDEU.

Posudek 2/15 pravděpodobně zcela neuspokojil ani jednu stranu. Jako se už stalo v minulosti mnohokrát, unijní instituce na jeho základech nicméně nalezly řešení, které by mělo umožnit naplňování společného cíle, tj. efektivního prosazování obchodní politiky EU při sjednávání obchodních a investičních dohod. Nový př́stup v podobě vyjednávání o investiční ochraně ve formě samostatných dohod je již uveden do praxe vủči Singapuru, Vietnamu a Japonsku. Lze navíc očekávat, že další partneři EU budou následovat. SDEU tak svým posudkem $2 / 15$ významným způsobem ovlivnil podobu současné i budoucí společné obchodní politiky Unie.

\author{
Mgr. Bc. Ondřej Svoboda \\ Právnická fakulta Univerzity Karlovy \\ ondrej.svobod@gmail.com
}

\footnotetext{
53 Usnesení Evropského parlamentu ze dne 5. července 2016 k nové a inovativní budoucí strategii pro obchod a investice (2015/2105(INI)), odst. 62, 88-90.

54 Posudek A-1/75, ECR 1355. 1975, bod 1363; Posudek A-1/78. ECR 287. 1979, body 43-53.

55 DÜR, A. - ELSIG, M. Introduction: The Purpose, Design and Effects of Preferential Trade Agreements. In DÜR, A. - ELSIG, M. (eds.). Trade Cooperation: The Purpose, Design and Effects of Preferential Trade Agreements. Cambridge: Cambridge University Press, 2015, s. 1, 19.
} 